\title{
DESENTRALISASI PENGELUARAN DI INDONESIA
}

\author{
Siti Herni Rochana \\ Universitas Winaya Mukti \\ sitiherni.roch@gmail.com
}

\begin{abstract}
.
Since the implementation of Law 22/1999 and Law 25/1999 of 2001, has been an increase in the implementation of fiscal decentralization with a phenomenon called Big Bang. The study was conducted to determine the degree of decentralization of expenditure covering the period before and after the implementation of regional autonomy. The research data is a panel data drawn from 30 provinces between 1994 to 2007. The results showed that in Indonesia there has been a significant increase in expenditure decentralization since 2001. Significant increases occurred mainly on the expenditure side, especially the decentralization of authority be spending more than doubled from the previous. On a national scale, the degree of decentralization of authority expenditure increased from $10.48 \%$ in the year 2000 to $25.45 \%$ in 2001 . And the average for each province, the degree of decentralization of spending authority increased from $0.40 \%$ in 2000 to 0, 85\% in 2001.
\end{abstract}

Keywords: Fiscal Decentralization; Regional Autonomy; Expenditure Decentralization.

\begin{abstract}
Abstrak.
Sejak pelaksanaan UU 22/1999 dan UU 25/1999 2001, telah terjadi peningkatan dalam pelaksanaan desentralisasi fiskal dengan fenomena yang disebut Big Bang. Penelitian ini dilakukan untuk mengetahui tingkat desentralisasi pengeluaran untuk periode sebelum dan setelah pelaksanaan otonomi daerah. Data penelitian adalah data panel yang diambil dari 30 provinsi antara tahun 1994 hingga 2007. Hasil penelitian menunjukkan bahwa di Indonesia telah terjadi peningkatan yang signifikan dalam desentralisasi pengeluaran sejak tahun 2001. Peningkatan yang signifikan terjadi terutama pada sisi pengeluaran, terutama desentralisasi kewenangan menghabiskan lebih dari dua kali lipat dari sebelumnya. Untuk skala nasional, derajat desentralisasi kewenangan pengeluaran meningkat dari 10,48\% pada Tahun 2000 menjadi 25,45\% pada Tahun 2001. Dan untuk rata-rata setiap provinsi, derajat desentralisasi kewenangan pengeluaran meningkat dari 0,40\% pada Tahun 2000 menjadi $0,85 \%$ pada Tahun 2001.
\end{abstract}

Kata Kunci: Desentralisasi Fiskal; Otonomi Daerah; Desentralisasi Pengeluaran.

Diterima: 2 Mei 2013; Direvisi: 2 Juli 2013; Disetujui: 9 Juli 2013 


\section{PENDAHULUAN}

Dalam beberapa dasawarsa terakhir, desentralisasi sedang menjadi trend arsitektur pemerintahan berkaitan dengan penyerahan sebagian urusan pada tingkat pemerintah yang lebih rendah. Hal ini didorong oleh kekecewaan terhadap dominasi pemerintah pusat yang dinilai belum memenuhi harapan masyarakat (Oates, 1999; Rodden, 2003). Pelaksanaan desentralisasi diharapkan dapat memberi dampak bagi peningkatan kesejahteraan rakyat melalui peningkatan kinerja perekonomian.

Di Indonesia, desentralisasi sebenarnya telah dilaksanakan sejak pemerintahan Hindia Belanda. Namun pada Tahun 2001 telah terjadi peningkatan yang signifikan dalam pelaksanaan desentralisasi fiskal yang dikenal dengan istilah The Indonesia's 2001 Big Bang Decentralization. Peningkatan yang signifikan dalam pelaksanaan desentralisasi fiskal pada 2001 dipicu oleh krisis ekonomi yang terjadi pada 1998. Dalam UU 22 Tahun 1999 dan UU 25 Tahun 1999 yang menjadi dasar pemberian otonomi yang lebih besar, dinyatakan bahwa tujuan desentralisasi adalah untuk meningkatkan kesejahteraan rakyat.

Sejarah pelaksanaan desentralisasi fiskal di Indonesia diatur dalam undang-undang tentang pemerintahan daerah dan undang-undang tentang hubungan keuangan pusat dan daerah. Sejak Orde Baru, telah keluar tiga undang-undang tentang pemerintahan daerah yaitu UU 5/1974, UU 22/1999, dan UU 32/2004. Demikian juga undang-undang tentang perimbangan keuangan pusat dan daerah diatur dalam UU 32/1956, UU 25/1999, dan UU 33/2004.

Pemberlakuan UU 22/1999 dan UU 25/1999 membawa perubahan besar dalam pelaksanaan desentralisasi fiskal di Indonesia. Sejak pelaksanaan kedua undang-undang tersebut pada Tahun 2001, telah terjadi peningkatan yang signifikan dalam pelaksanaan desentralisasi fiskal yang disebut dengan fenomena Big Bang.

Perubahan dalam pelaksanaan desentralisasi fiskal tercermin dari perubahan dalam APBN (Anggaran Pendapatan dan Belanja Negara) dan APBD (Anggaran Pendapatan dan Belanja Daerah). Dalam UU 17/2003 tentang Keuangan Negara disebutkan bahwa APBN adalah rencana keuangan tahunan pemerintahan negara yang disetujui oleh DPR. Sementara APBD adalah rencana keuangan tahunan pemerintahan daerah yang disetujui oleh DPRD. 
Tabel 1. Penerimaan APBD Sebelum dan Setelah Tahun Anggaran 2001

\begin{tabular}{clcl}
\hline No. & Komponen Penerimaan & \multicolumn{1}{c}{ Sebelum TA 2001 } & \multicolumn{1}{c}{ Setelah TA 2001 } \\
\hline 1 & $\begin{array}{l}\text { Penerimaan sendiri } \\
\text { (Own revenue })\end{array}$ & Pendapatan Asli Daerah & $\begin{array}{l}\text { Pendapatan Asli } \\
\text { Daerah }\end{array}$ \\
2 & $\begin{array}{l}\text { Penerimaan bagi hasil } \\
\text { (Shared revenue })\end{array}$ & Dana Bagi Hasil & $\begin{array}{l}\text { Dana Bagi Hasil } \\
\text { Dana Otonomi }\end{array}$ \\
& & & Khusus \\
3 & $\begin{array}{l}\text { Bantuan umum } \\
\text { (General purpose grant) }\end{array}$ & Instruksi Presiden Umum & Dana Alokasi Umum \\
4 & $\begin{array}{l}\text { Bantuan khusus } \\
\text { (Specific purpose grant) }\end{array}$ & Subsidi Daerah Otonom & Dana Alokasi Khusus \\
& &
\end{tabular}

Sumber: Kemenkeu (2004), Kemenkeu (2006), Shah dan Qureshi (1994), Bambang dan Martinez- Vazquez (2002), Hofman dkk. (2006), Silver dkk. (2001), Devas (2008).

Seiring dengan fenomena Big Bang, sejak Tahun 2001 terjadi perubahan nama atau istilah untuk beberapa komponen penerimaan APBD. Komponen penerimaan APBD sebelum 2001 adalah Pendapatan Asli Daerah (PAD), Dana Bagi Hasil (DBH), Subsidi Daerah Otonom (SDO) dan Instruksi Presiden (Inpres). Sementara komponen penerimaan APBD setelah 2001 adalah Pendapatan Asli Daerah (PAD), Dana Bagi Hasil (DBH), Dana Alokasi Umum (DAU), dan Dana Alokasi Khusus (DAK). Selain itu sejak Tahun Anggaran 2001 terdapat Dana Otonomi Khusus untuk Aceh dan Papua (Kemenkeu, 2006). Perubahan nama atau istilah dari komponen penerimaan APBD dapat dilihat pada Tabel 1.

Secara umum desentralisasi fiskal dapat diartikan sebagai penyerahan sebagian urusan pengelolaan anggaran dari pemerintah pusat kepada pemerintah daerah. Desentralisasi fiskal pada dasarnya adalah transfer tugas dan tanggung jawab pengeluaran dan penerimaan pada tingkat pemerintahan yang lebih rendah (Bank Dunia, 2008). Para ahli mengemukakan konsep-konsep desentralisasi fiskal dari berbagai sudut pandang mengenai penyerahan sebagian urusan, tugas, dan tanggung jawab pengelolaan anggaran. Dari konsep-konsep tersebut ada konsep yang diistilahkan dengan desentralisasi dan ada konsep yang diistilahkan dengan otonomi, namun kedua istilah tersebut sama-sama menggambarkan penyerahan urusan pengelolaan anggaran.

Terdapat empat konsep berkaitan dengan desentralisasi fiskal yaitu: (1) Desentralisasi fiskal adalah penyerahan tugas fiskal (Oates, 1972; Stegarescu, 2005), (2) 
Desentralisasi fiskal adalah penyerahan kewenangan fiskal (Akai dan Sakata, 2002; Stegarescu, 2005), (3) Otonomi fiskal adalah kemandirian fiskal pemerintah daerah (Akai dan Sakata, 2002), dan (4) Otonomi fiskal adalah daya kontrol pemerintah daerah atas penerimaannya sendiri (Ebel dan Yilmaz, 2002).

Desentralisasi fiskal sebagai penyerahan tugas adalah pemerintah pusat menyerahkan sebagian tugas untuk melaksanakan (assignment) pengeluaran dan penerimaan anggaran kepada pemerintah daerah (Oates, 1972; Stegarescu, 2005). Desentralisasi fiskal sebagai penyerahan kewenangan adalah pengeluaran dan penerimaan anggaran kepada pemerintah daerah (Akai dan Sakata (2002). Otonomi fiskal sebagai kemandirian fiskal (fiscal independence) adalah kemandirian pemerintah daerah atas penerimaan daerah dan tidak tergantung pada transfer dari pemerintah pusat (Akai dan Sakata, 2002). Otonomi fiskal sebagai daya kontrol pemerintah daerah adalah pemerintah daerah memiliki kontrol atas penerimaannya sendiri (Ebel dan Yilmaz, 2002).

Selanjutnya desentralisasi fiskal dapat ditinjau dari dua dimensi yaitu desentralisasi pengeluaran dan desentralisasi penerimaan. Dari konsep desentralisasi fiskal sebagai penyerahan tugas, desentralisasi pengeluaran adalah penyerahan tugas untuk melaksanakan pengeluaran, sedangkan desentralisasi penerimaan adalah penyerahan tugas untuk melaksanakan penerimaan. Sementara dari konsep desentralisasi fiskal sebagai penyerahan kewenangan, desentralisasi pengeluaran adalah penyerahan kewenangan untuk membuat keputusan pengeluaran baik keputusan mengenai peruntukan maupun besar pengeluaran untuk setiap peruntukan.

\section{METODE}

Unit analisis pada penelitian ini adalah provinsi. Data diambil dari 30 provinsi di Indonesia. Periode penelitian adalah 14 tahun meliputi periode sebelum dan setelah Otonomi Daerah sejak Tahun 2001 sebagai bentuk pelaksanaan UU 22/1999 dan UU 25/1999 yaitu tahun 1994 sampai 2007. Dengan demikian jenis data penelitian adalah data panel.

Dalam penelitian ini, penulis menggunakan dua konsep desentralisasi fiskal yaitu desentralisasi fiskal sebagai penyerahan tugas fiskal dan desentralisasi fiskal sebagai penyerahan kewenangan fiskal. Desentralisasi fiskal sebagai penyerahan tugas adalah pemerintah pusat menyerahkan sebagian tugas 
(assignment) untuk melaksanakan pengeluaran dan penerimaan anggaran kepada pemerintah daerah. Desentralisasi fiskal sebagai penyerahan kewenangan adalah pemerintah pusat menyerahkan sebagian kewenangan untuk membuat keputusan (make of decisions) pengeluaran dan penerimaan anggaran kepada pemerintah daerah. Dengan demikian variabel desentralisasi pengeluaran dilihat dari dua konsep yaitu desentralisasi tugas pengeluaran (X1.1), desentralisasi kewenangan pengeluaran (X1.2). Pengukuran kedua variabel tersebut dapat dilihat pada Tabel 2.

Khusus untuk data APBD, terdapat perbedaan periode tahun anggaran pada sebelum dan setelah Tahun Anggaran 2001. Sebelum Tahun 2001, tahun anggaran APBD dimulai dari 1 April sampai dengan 31 Maret tahun berikutnya. Sementara sejak Tahun 2001, tahun anggaran APBD sama dengan tahun kalender yaitu dimulai dari 1 Januari sampai dengan 31 Desember. Sementara pada Tahun Anggaran 2000, periode APBD hanya berlangsung sembilan bulan yang dimulai 1 April sampai 31 Desember. Untuk memperoleh keseragaman periode varibel penelitian maka periode tahun anggaran APBD sebelum 2001 digeser menjadi sama dengan tahun kalender. Pertama, besar APBD untuk setiap kuartal dihitung dengan metode interpolasi.

\section{HASIL DAN PEMBAHASAN}

Derajat desentralisasi tugas pengeluaran dan desentralisasi kewenangan pengeluaran di Indonesia periode Tahun Anggaran 1994-1995 sampai 2007 dapat dilihat pada Tabel 1. Derajat desentralisasi kewenangan pengeluaran yang sebenarnya untuk periode sebelum tahun 2001 tidak dapat dihitung karena komponen inpres khusus tidak dapat diidentifikasi.

Tetapi untuk memperoleh gambaran, penulis melakukan pendekatan pengukuran derajat desentralisasi kewenangan pengeluaran. Pendekatan pengukuran dilakukan dengan mengurangi pengeluaran APBD dengan SDO saja. Dengan demikian angka sebenarnya derajat desentralisasi kewenangan sebelum Tahun 2001 lebih rendah dari angka pendekatan yang diperoleh (karena seharusnya dikurangi oleh SDO dan inpres khusus). Untuk mencirikan bahwa angka tersebut adalah angka pendekatan, maka derajat desentralisasi kewenangan pengeluaran pada Tabel 2 ditandai dengan pagar, 
sementara kurva derajat desentralisasi kewenangan pengeluaran pada Gambar 1 digambarkan dengan garis putus-putus.

Derajat desentralisasi pengeluaran di Indonesia mengalami perubahan besar sejak Tahun 2001. Derajat desentralisasi pengeluaran baik dari konsep tugas maupun kewenangan meningkat signifikan pada Tahun 2001. Hal ini sesuai dengan apa yang diungkapkan oleh Bank Dunia sebagai The Indonesia's Big Bang Fiscal Decentralization (Bank Dunia, 2003). Istilah ini diberikan karena hanya dalam waktu yang singkat, Indonesia mengalami peningkatan besar dalam pelaksanaan desentralisasi fiskal.

Hal menarik untuk diamati adalah adanya perbedaan antara derajat desentralisasi tugas pengeluaran dan desentralisasi kewenangan pengeluaran. Terkait dengan fenomena big bang pada Tahun 2001, perubahan yang lebih besar ternyata terjadi dalam pelaksanaan desentralisasi kewenangan pengeluaran. Untuk skala nasional, derajat desentralisasi kewenangan pengeluaran meningkat dari 10,48\% pada Tahun 2000 menjadi 25,45\% pada Tahun 2001, dan untuk rata-rata setiap provinsi, derajat desentralisasi kewenangan pengeluaran meningkat dari 0,40\% pada Tahun 2000 menjadi $0,85 \%$ pada Tahun 2001. Sementara derajat desentralisasi tugas pengeluaran untuk skala nasional meningkat dari 17,28\% pada Tahun 2000 menjadi 25,77\% pada Tahun 2001. Dan untuk rata-rata setiap provinsi, derajat desentralisasi tugas pengeluaran meningkat dari $0,66 \%$ pada Tahun 2000 menjadi $0,86 \%$ pada Tahun 2001.

Fenomena Big Bang memang terjadi pada Tahun 2001 jika kita melihat perubahan dari Tahun 2000. Tetapi kalau dilihat lebih ke belakang khususnya untuk desentralisasi tugas pengeluaran, Indonesia telah mengalami derajat desentralisasi tugas pengeluaran cukup tinggi pada sebelum 2001. Pada Tahun Anggaran 1994-1995 sampai 1996-1997, derajat desentralisasi tugas pengeluaran adalah diatas 30\% (Gambar 1). 
Tabel 2.

Derajat Desentralisasi Tugas Pengeluaran dan Desentralisasi Kewenangan Pengeluaran Tahun Anggaran 1994-1995 Sampai 2007 di Indonesia Desentralisasi Tugas Desentralisasi Kewenangan

\begin{tabular}{cccccc} 
No. & $\begin{array}{c}\text { Tahun } \\
\text { Anggaran }\end{array}$ & Indonesia & $\begin{array}{c}\text { Rata-rata per } \\
\text { Provinsi }\end{array}$ & Indonesia & $\begin{array}{c}\text { Rata-rata per } \\
\text { Provinsi }\end{array}$ \\
\cline { 3 - 6 } & & 30,18 & 1,16 & $17,50^{\#}$ & $0,67^{\#}$ \\
\hline 1 & $1994-1995$ & 33,24 & 1,28 & $19,85^{\#}$ & $0,76^{\#}$ \\
\hline 2 & $1995-1996$ & 31,66 & 1,22 & $19,41^{\#}$ & $0,75^{\#}$ \\
\hline 3 & $1996-1997$ & 28,77 & 1,11 & $17,17^{\#}$ & $0,66^{\#}$ \\
\hline 4 & $1997-1998$ & 21,31 & 0,82 & $12,48^{\#}$ & $0,48^{\#}$ \\
\hline 5 & $1998-1999$ & 25,89 & 1,00 & $14,77^{\#}$ & $0,57^{\#}$ \\
\hline 6 & $1999-2000$ & 17,28 & 0,66 & $10,48^{\#}$ & $0,40^{\#}$ \\
\hline 7 & 2000 & 25,77 & 0,86 & 25,45 & 0,85 \\
\hline 8 & 2001 & 33,84 & 1,13 & 33,23 & 1,11 \\
\hline 9 & 2002 & 35,90 & 1,20 & 34,71 & 1,16 \\
\hline 10 & 2003 & 33,03 & 1,10 & 32,15 & 1,07 \\
\hline 11 & 2004 & 31,25 & 0,98 & 30,43 & 0,95 \\
\hline 12 & 2005 & 34,56 & 1,08 & 33,02 & 1,03 \\
\hline 13 & 2006 & 38,39 & 1,16 & 36,22 & 1,10 \\
\hline 14 & 2007 & & & &
\end{tabular}

\# Angka pendekatan

Gambar 1.

Derajat Desentralisasi Tugas Pengeluaran dan Desentralisasi Kewenangan Pengeluaran Tahun Anggaran 1994-1995 Sampai 2007 di Indonesia

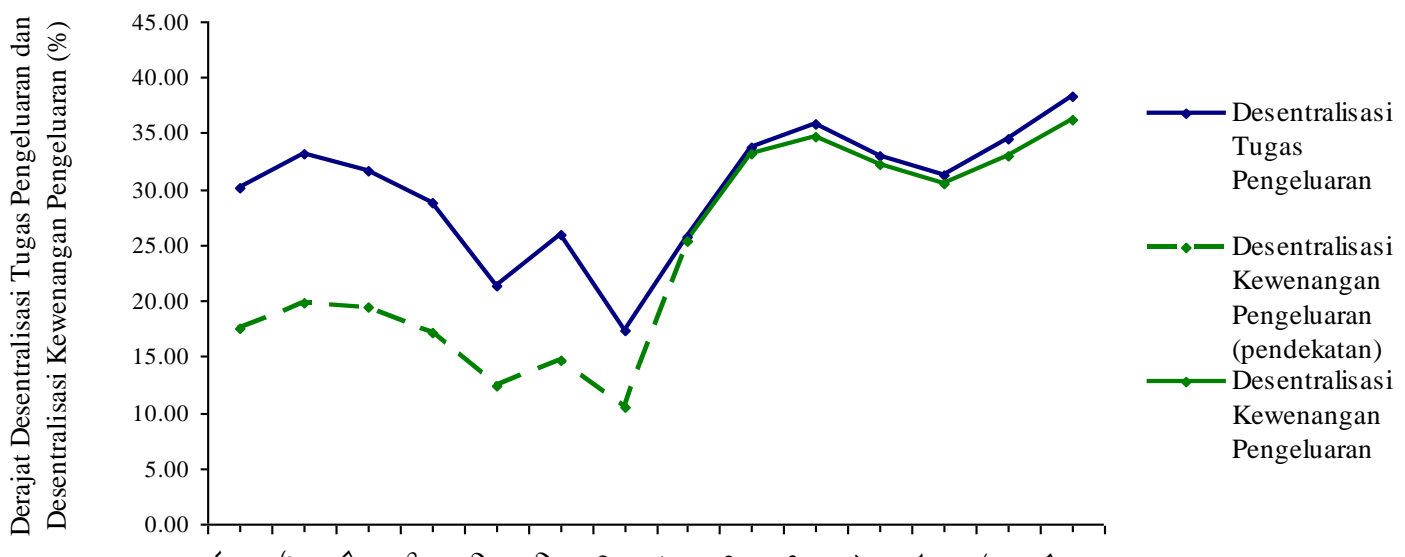

Tahun Anggaran 
Kenaikan signifikan dalam derajat desentralisasi pengeluaran di Indonesia sejak Tahun 2001 terjadi akibat implementasi kebijakan Otonomi Daerah yang tertuang dalam UU 22/1999 tentang Pemerintahan Daerah dan UU 25/1999 tentang Perimbangan Keuangan antara Pemerintah Pusat dan Daerah. Sejak pemberlakuan Otonomi Daerah, urusan pemerintahan banyak dilimpahkan ke daerah. Sesuai dengan prinsip money follows function, anggaran untuk penyelenggaraan urusan tersebut di transfer ke daerah.

Seiring dengan pelaksanaan otonomi daerah dan desentralisasi fiskal, sejak tahun 2001 transfer dana dari APBN ke daerah dialokasikan dalam bentuk dana perimbangan. Pengalokasian dana perimbangan ini selain ditujukan untuk memberikan kepastian sumber pendanaan bagi APBD, juga bertujuan untuk mengurangi/ memperkecil perbedaan kapasitas fiskal antardaerah. Sebelum tahun 2001, perimbangan keuangan pusat dan daerah dalam APBN diwujudkan melalui alokasi pengeluaran transfer kedaerah, berupa (i) subsidi daerah otonom (SDO) atau dana rutin daerah (DRD), dan (ii) anggaran yang didaerahkan dalam bentuk dana pembangunan daerah (DPD) termasuk dana bagi hasil PBB dan BPHTB. Rasio jumlah pengeluaran transfer kedaerah dalam bentuk DRD dan DPD termasuk bagi hasil PBB dan BPHTB terhadap PDB terus meningkat dari 2,6\% dalam Tahun Anggaran 1999/2000 menjadi 3,4\% dalam Tahun Anggaran 2000. Sedangkan pada tahun 2001 dana perimbangan diperkirakan sebesar $\mathrm{Rp} 82,4$ triliun atau 5,6\% terhadap PDB, yang masing-masing berupa dana bagi hasil (DBH) 1,4\% terhadap PDB, dana alokasi umum (DAU) 4,1\% terhadap PDB, dan dana alokasi khusus (DAK) 0,05\% terhadap PDB (Nota Keuangan 2001).

Fenomena lain yang menarik untuk diamati adalah bahwa pada Tahun 2001 desentralisasi tugas pengeluaran hampir sama dengan desentralisasi kewenangan pengeluaran, dimana derajat desentralisasi tugas pengeluaran $25,77 \%$ dan derajat desentralisasi kewenangan pengeluaran 25,45\% untuk skala nasional. Hal ini menunjukan bahwa hampir seluruh anggaran yang ditransfer pemerintah pusat kepada pemerintah daerah (yang terdiri dari DBH, DAU, dan DAK) penggunaannya diserahkan kepada daerah. Dengan kata lain, daerah diberi kewenangan untuk menentukan peruntukan dari dana yang ditransfer oleh pemerintah pusat. Hanya DAK saja yang peruntukannya ditentukan oleh pemerintah pusat. Tetapi pada Tahun 2001, DAK relatif kecil yaitu Rp. 700,6 milyar dari seluruh dana perimbangan yang ditransfer sebesar Rp. 82,4 triliun atau hanya sekitar 0,85\% (Nota Keuangan, 2001). Hal ini 
menyebabkan derajat desentralisasi kewenangan pengeluaran hampir menyamai derajat desentralisasi tugas pengeluaran.

Kemudian setelah Tahun 2001, desentralisasi pengeluaran di Indonesia terus meningkat berada diatas 30\%. Pada Tahun 2002 desentralisasi tugas pengeluaran adalah 33,84\% dan pada Tahun 2007 mencapai 38,39\%. Besarnya derajat desentralisasi pengeluaran di Indonesia setelah Otonomi Daerah dapat disejajarkan dengan negara-negara maju seperti Amerika Serikat 40,0\%, Norwegia 38,8\% dan ratarata negara-negara OECD $32.2 \%$.

Tabel 3.

Derajat Desentralisasi Pengeluaran dan Desentralisasi Penerimaan di Negaranegara Maju Tahun 2001

\begin{tabular}{lcc}
\hline \multicolumn{1}{c}{ Negara } & $\begin{array}{c}\text { Desentralisasi } \\
\text { Pengeluaran (\%) }\end{array}$ & $\begin{array}{c}\text { Desentralisasi } \\
\text { Penerimaan (\%) }\end{array}$ \\
\hline Amerika Serikat & 40,0 & 40,4 \\
Norwegia & 38,8 & 20,3 \\
Perancis & 18,6 & 13,1 \\
Denmark & 57,8 & 34,6 \\
Portugal & 12,8 & 8,3 \\
Yunani & 5,0 & 3,7 \\
OECD (rata-rata) & 32,2 & 21,9 \\
\hline
\end{tabular}

Sumber: Gruber (2007)

\section{SIMPULAN}

$\mathrm{Di}$ Indonesia telah terjadi peningkatan yang signifikan dalam pelaksanaan desentralisasi fiskal sejak Tahun 2001. Peningkatan yang signifikan terutama terjadi pada sisi pengeluaran khususnya desentralisasi kewenangan pengeluaran yang menjadi lebih dari dua kali lipat dari sebelumnya Besarnya derajat desentralisasi pengeluaran di Indonesia setelah Otonomi Daerah dapat disejajarkan dengan negaranegara maju seperti Amerika Serikat 40,0\%, Norwegia 38,8\% dan rata-rata negaranegara OECD $32.2 \%$.

\section{PUSTAKA ACUAN}

Akai, Nobuo and Mayaso Sakata. 2002. Fiscal Decentralization Contributes to Economic Growth: Evidence from State-Level Cross-Section Data for The United States. Journal of Urban Economics 52 : 93-108.

Devas, Nick. 2008. Financing Local Government. London: Commonwealth Secretariat. 
Ebel, Robert D., and Serdar Yilmaz. 2002. On the Measurement and Impact of Fiscal Decentralization. World Bank Policy Research Working Paper 2809.

Gruber, Jonathan. 2007. Public Finance and Public Policy. Second Edition. New York: Worth Publisher.

Martinez-Vazquez, Jorge and Robert M. McNab 2003. Fiscal Decentralization and Economic Growth. World Development 31(9) : 1597-1616.

Oates, Wallace E. 1999. An Essay of Fiscal Federalism. Journal of Economic Literature $37(3): 1120-1149$.

Rodden, Jonathan A., Gunnar S. Eskeland, and Jennie Litvack. 2003. Fiscal Decentralization and the Challenge of Hard Budget Constraints. Cambridge: The MIT Press.

Rosen, Harvey S., and Ted Gayer. 2008. Public Finance. Eight Edition. New York: McGraw-Hill.

Silver, Christopher, Iwan J. Azis, and Larry Schroeder. 2001. Intergovernmental Transfers and Decentralisation in Indonesia. Bulletin of Indonesian Economic Studies 37(3) : 345-362.

Stegarescu, Dan. 2005. Public Sector Decentralisation: Measurement Concepts and Recent International Trends. Fiscal Studies 26(3) : 301-333.

Tresch, Richard. W. 2002. Public Finance. A Normative Theory. Second Edition. San Diego: Academic Press.

World Bank. 2003. Decentralizing Indonesia. A Regional Public Expenditure Review. Overview Report No. 26191-IND. Melalui http://www.wds.worldbank.org/external/default/WDSContentServer/WDSP/IB/20 03/07/29/000160016 20030729123554/Rendered/PDF/261910ID0ESW.pdf [711-08]. diakses pada 10 Juni 2013 